\title{
The use of virtual communities of practice to improve interprofessional collaboration and education: Findings from an integrated review
}

Clodagh McLoughlin ${ }^{1}$, Kunal D Patel ${ }^{1,2}$, Tom O’Callaghan ${ }^{1}$ and Scott Reeves ${ }^{2}$

Corresponding Author: Clodagh McLoughlin

iheed,

$7^{\text {th }}$ Floor,

Russel Building,

Tallaght Cross West,

Dublin 24,

Ireland

m clodagh@hotmail.com

\footnotetext{
${ }^{1}$ iheed, Dublin, Ireland

${ }^{2}$ Faculty of Health, Social Care \& Education, Kingston University \& St Georges, University London, UK
} 


\begin{abstract}
The recent growth in online technology has led to a rapid increase in the sharing of health related information globally. Health and social care professionals are now using a wide range of virtual communities of practice (VCoPs) for learning, support, continuing professional education, knowledge management and information sharing. In this paper we report the findings from a review of the literature that explored the use of VCoPs by health and social care professionals to determine their potential for interprofessional education and collaboration. We employed an integrated literature review to search and identify relevant VCoP papers. We undertook searches of PubMed and Google Scholar from 2000, which after screening resulted in including 19 papers. A thematic analysis generated the following key issues related to the use of VCoPs: 'definitions and approaches', 'technological infrastructure', 'reported benefits', 'participation issues', 'trust and privacy and 'technical ability'. Based on the findings from this review, there is some evidence that VCoPs can offer an informal method of professional and interprofessional development for clinicians, and can decrease the social and professional isolation. However for VCoPs to be successful, issues of privacy, trust, encouragement and technology need to be addressed.
\end{abstract}

Keywords: Communities of practice; virtual communities of practice; interprofessional collaboration; interprofessional education; social media; internet

\title{
Introduction
}

Globally, it has been reported that there is often a mismatch between what health professionals are competent to do and what the populations they serve actually require (World Health Organization, 2013). The Lancet Commission on Education of Health Professionals for the 21 st Century stated that this is due to "fragmented, outdated, and static 
curricula that produce ill-equipped graduates" (Frenk et al., 2010, p. 1923). Current methods of education have arguably failed to overcome inequitable health systems lacking universal health coverage, due to their curricula rigidities, professional silos and limited adaptation to local context. This failure is especially evident within primary care where the need to break down professional silos via interprofessional education (IPE) is necessary (Frenk et al., 2010; Lygidakis, McLoughlin, \& Patel, 2016). Indeed, primary care is crucial for providing equitable health systems which offer cost effective health coverage, while also being able to manage almost all health care demands. Within this sector, as within other health care sectors, interprofessional teams are essential to delivering comprehensive and coordinated care that is capable of tackling the ever growing challenges facing health systems globally (e.g. Reeves, Lewin, Espin \& Zwarenstein, 2010; Lygidakis et al., 2016).

Recognising the importance of interprofessional teamwork and collaboration for producing high quality patient care, there has been growing support for educating health and social care professionals in collaborative practice competencies by the use of IPE, to complement the development of clinical skills (e.g. King, Greidanus, Carbonaro, Drummond, \& Patterson, 2009). Ideally, IPE should be offered at the start of a professional's education and occur regularly throughout their career (e.g. Reeves, Perrier, Goldman, Freeth, \& Zwarenstein, 2013; Reeves et al., 2016). Systematic reviews of interprofessional interventions have found that the use of IPE and collaboration (IPC) is critical to improving the delivery of effective care, as well as generating a range of positive health outcomes (Reeves et al., 2013; Reeves, Pelone, Harrison, Goldman \& Zwarenstein, 2017).

A key approach to supporting IPE and IPC has been the use of communities of practice (COPs) (e.g. Lee \& Meyer 2010; Peu et al., 2014). This approach, with a group of individuals 
with common interests come together to collaborate, can facilitate information sharing and knowledge translation as well as sharing best practices and building professional and interprofessional capacity (Ford, Korjonen, Keswani, \& Hughes, 2015). See Table 1 for an overview of short term and long benefits of CoPs.

\section{INSERT TABLE 1 ABOUT HERE}

Internet use has grown globally and is recognised as a powerful tool for sharing of information and communicating as seen via such as wikis and social media (Honeycutt \& Herring, 2009). As a result of this growth, information and communications technology (ICT) is being increasingly used to overcome silos; promoting IPE and IPC and facilitating health care professions to work together (e.g. King et al., 2009). This growth in online technology has led to an increase in the sharing of health related information globally; health professionals are now using a wide range of virtual communities of practice (VCoPs) (Barnett, Jones, Bennett, Iverson, \& Robinson, 2016). The main driver for such online communities being the desire to create networks of people with common interests who are geographically dispersed (Barnett, Jones, Bennett, Iverson, \& Bonney, 2012). They have also shown to be successful in developing and implementing health service improvement strategies (Abos Mendizabal, Nuño Solinís, \& Zaballa González, 2013), knowledge sharing between rural and urban health care providers and clinics (Curran, Murphy, Abidi, Sinclair, \& McGrath, 2009), supporting evidence based practice (Evans, Yeung, Markoulakis, \& Guilcher, 2014) and show potential for reducing rural isolation and supporting collaboration of general practitioners, and in mental health practice (Barnett et al., 2014; Cassidy, 2011).

Facilitated by social media platforms, blogs and discussion forums, VCoPs aid knowledgesharing in situations where opportunities to interact on a face-to-face basis are constrained by geography, cost and time differences (Ikioda, Kendall, Brooks, \& Reidy, 2014). Due to their 
ability to facilitate two-way communication, VCoPs can be considered as a useful vehicle for IPE and IPC, especially for those working in remote or rural areas.

Despite their emergence, there has been limited interest in examining the application of VCoPs for IPE and IPC. This paper aims to explore the VCoP literature to determine the potential use for supporting IPE and IPC activities. In doing so, we aimed to generate an understanding the strengths and limitations of this approach can to provide guidance on how and when they might be effective within an interprofessional context.

\section{Methods}

We employed an integrative review as this approach aims to provide an exploratory insight of the literature in a particular domain, as it includes a wide sampling frame and can include findings from diverse methodologies (Whittemore \& Knafl, 2005).

\section{Searching and screening}

A broad search of the VCoP literature was conducted on PubMed and Google Scholar using a combination of key terms, including, "Community of Practice", "Virtual Community of Practice", "Online Community of Practice” AND “interprofessional” to identify any papers which reported on the use of VCoPs. A date range from 2000 to 2016 was selected to account for the relatively recent global growth in internet use. Only journal articles in English were selected. A total of 79 abstracts were initially found from the searches. All abstracts were screened by the authors for those that focused on online CoP, or VCoP within a healthcare (clinical or educational) setting. Papers with patients using VCoPs were excluded if focus of was on patient education rather than health professional learning or collaboration. From this process, the full texts of 19 articles were included. 


\section{Analysis and synthesis}

Key information from the included papers was abstracted by one of the authors. The following information was obtained from each paper: study setting, study designs; sample sizes and data collected. A thematic approach to the analysis of each abstracted text was employed to generate a series of key issues/themes.

\section{Results}

A list of included papers is presented in Table 2. As indicated in this table, nine studies were based in primary care settings, six in mixed settings (primary care, secondary care and/or higher education locations), two in educational settings and two in secondary care settings. In terms of study design, while the bulk of papers $(n=11)$ employed a case study approach, other papers described the use of a range of different designs, such as observational study design, quasi-experimental cohort study, mixed methods and Q-methodology. In regards to data collection, most of the studies employed a mix of qualitative methods, however, six studies employed web analysis (i.e. use of web or internet data). Samples sizes of these studies ranged from 16 to 620 participants. In addition to the empirical study papers, we found three papers which reported the findings from reviews of the VCoP literature.

\section{INSERT TABLE 2 ABOUT HERE}

\section{Key issues}

Below we present key findings from the analysis of the included papers in the following six sections: 'definitions and approaches', 'technological infrastructure', 'reported benefits', 'participation issues', 'trust and privacy and 'technical ability'. 
Definitions and approaches. As many of the included papers noted, the term CoPs was first used to describe a mode of learning based upon an apprenticeship model (Wenger, 1998). This concept was subsequently expanded to include informal collaboration among practitioners of all levels to solve problems through knowledge sharing (King et al., 2009; Valaitis, Akhtar-Danesh, Brooks, Binks, \& Semogas, 2011). CoPs have evolved to refer to a community where members share a common interest and, in turn, share their knowledge and experience about that interest, allowing members to learn from each other. Members can then apply this knowledge to their practice (Stewart \& Abidi, 2012).

CoPs were successfully adopted by the business sector, and more recently by education and health care sectors (Barnett et al., 2012). Within health and social care, CoPs have been commonly used for student learning, support, continuing professional education, knowledge management and information sharing (King et al., 2009). Due to the growth in the internet and online technology the use of VCoPs have rapidly expanded. Their growing use has been associated with both a breakdown of geographical and hierarchical barriers often experienced in traditional CoPs (Mairs, McNeil, McLeod, Prorok, \& Stolee, 2013).

Technological infrastructure. A number of the papers reported technological infrastructure issues with the use of VCoPs. Tools such as discussion forums and social networks have been reported to offer virtual environments where VCoPs can take place, allowing members from different geographical locations, different professions and different levels of experience to collaborate within a community (e.g. Stewart \& Abidi, 2012).

Social networking sites (e.g. Facebook, Twitter, LinkedIn) ${ }^{1}$ have been reported to provide an innovative and convenient way for users to communicate, establish and maintain connections 
with others based on their interests (Lofters, Slater, Nicholas Angl, \& Leung, 2016). These network sites have become a popular choice for VCoPs due to their accessibility on multiple electronic devices allowing users to work more flexibly (Maisonneuve, Chambe, Lorenzo, \& Pelaccia, 2015). It was been reported that most university students use social networking sites and have gained substantial skills in using them - skills which can later be transferred to a professional setting (King et al., 2009).

Social network sites can be used by VCoPs in numerous ways by different health and social care professionals. For example, it was reported that they have can disseminate health information, provide information on available local resources, publicise educational events, and receive feedback from colleagues. One of the included studies reported that over $24 \%$ of respondents used social media on a daily basis to explore clinical information (Lofters et al., 2016). The popularity of Facebook, in particular, was due to the fact that organisations can create both pages and groups, which can provide user analytics and also have stringent privacy settings. Twitter has been increasingly used to 'live tweet' (post comments about an event while it is taking place) during a conference, while the use of 'twitter chats' (a moderated discussion on a single topic) is also expanding within VCoPs. Furthermore, LinkedIn has been reported as an effective means of continuing professional and interprofessional development due to a variety of different learning resources and information users post on a daily basis (Dong, Cheema, Samarasekera, \& Rajaratnam, 2015). Other social networking sites specific to health care professionals have also emerged, including Doximity ${ }^{2}$ - a website for clinicians which allows them to connect with colleagues and earn continuing educational credits (Lofters et al., 2016). 
Online discussion forums, groups or electronic boards, are another popular format for VCoPs. These technologies engage participants in an asynchronous knowledge transfer dialogue where explicit and experiential knowledge can be disseminated. Involvement in such activities can assist knowledge transfer by allowing participants to see how knowledge can be applied to their clinical context (Stewart \& Abidi, 2012). Members can post messages and expect to receive responses to their messages. The social nature of these forums, groups or electronic boards has also been found to be a key component to their success. In particular, it have been reported that they can assist in the formation of new relationships and strengthening existing ones, creating a sense of community (Mairs et al., 2013).

However, a number of the papers note that ethical considerations must be considered when adopting social networks as a platform for VCoPs, including concerns over privacy and security (Barnett, Jones, Bennett, Iverson, \& Bonney, 2013; Lofters et al., 2016). These considerations cover not only online security, but also the privacy of personal and patient information which may be shared on these networks - elements which can create barriers to their use.

Reported benefits. The papers reported a number of benefits to using VCoPs for health and social care professionals. For example, the creation of a VCoP has been found to successfully support the development of professional and interprofessional learning, the consultation of patient issues and the discussion of clinical challenges (e.g. Lofters et al., 2016). It was reported that VCoPs are becoming more targeted in their focus, specifically on sharing and promoting evidence-based practice which has resulted from members drawing on expertise from research, clinical experience, patients, carers and their local context (Ikioda et al., 2014; Swift, 2014). 
The sense of community, empowerment and ownership in CoPs can help in breaking down professional silos and isolation. VCoPs have been found to be provide an open, equitable and accessible knowledge transfer medium for health and social care practitioners, especially those who have encountered hierarchical barriers to gaining knowledge and sharing information (Stewart \& Abidi, 2012). However, organisations with steep vertical hierarchies can inhibit knowledge sharing in a VCoP. In these organisations managers often monitor and control the flow of information, which can impede the free flow of information and knowledge sharing between different professions within and between their organisations (Swift, 2014).

It has been noted that for researchers, VCoPs can provide an interactive forum to work together within a protected environment in which data can be shared, collaborative thinking can be nurtured and ideas openly discussed and debated. In particular, VCoPs can allow members to share information with little effort but with high value return, they can introduce members to new experts and resources, they can also facilitate a greater uptake of best practices by individual practitioners and promote professional and interprofessional continuing development which is both team-based and patient-centred (Lygidakis et al., 2016; Mairs et al., 2013).

A number of the included papers noted that VCoPs can also provide a risk-free environment for members which can encourage active participation, which can break down traditional professional barriers to the development of IPE and IPC activities. Ensuring the VCoP has a positive and encouraging environment can help to build trust and improve communication (e.g. Barnett et al., 2012), which allows participants to feel comfortable sharing with the 
community, or interacting with other members, even those of a different profession or in a more senior position.

It was also noted that VCoPs can facilitate a reduction in professional isolation and aid the retention of health professionals, especially in rural areas where educational opportunities and support can be limited. Traditional IPE and IPC activities are especially challenging to establish and sustain in rural areas due to limited staff numbers and resources. However, a shift to VCoPs in such areas has been found to have promise to the development of vitural forms of IPE and IPC (e.g. Pullon et al., 2016). VCoPs can have a particularly positive impact on the development and support for isolated clinicians by providing them with a community to engage in, learn from and seek support from (e.g. Mairs et al., 2013; Swift, 2014). While it is important to note that membership of a VCoP can overcome barriers of time/space, relationships are strengthened through the use of face-to-face meetings. Indeed, blending the virtual and real environments has been reported as highly desirable for creating and sustaining effective professional and interprofessional relationships (e.g. Barnett et al., 2012). 
Participation issues. A number of the papers reported participation issues related to VCoPs. It has been found that virtual communities succeed when there is a desire to share knowledge and experiences with the community. However, when participation is neither required nor requested by the community, involvement can be limited and fragmented (e.g. Stewart \& Abidi, 2012). Many of the included papers report that a large proportion of VCoP members function in the role of 'lurkers' (members who do not actively participate). As VCoPs depend on active participants for content, it is essential to foster participation of all members by encouraging a wide contribution of members to the discussions. Through engaging noncontributing participants with those who actively share it is possible to strengthen the sharing and flow of knowledge throughout the community. Indeed, it has been suggested that tools should be developed to allow 'lurkers' to connect with those contributing knowledge, while active knowledge sharers need mechanisms to inform them when their contributions are used (Spallek et al., 2008; Stewart \& Abidi, 2012). Nevertheless, it has been suggested that lurking can actually be a first step for individuals who are apprehensive about using ICT, or whose lack confidence or experience (Swift, 2014). Indeed, one of the included studies found that $80 \%$ of respondents stated that discussions on the VCoP had been useful, even though $96 \%$ had not been active participants (Abos Mendizabal et al., 2013).

Time has been identified as a significant barrier for participating in VCoPs (Barnett et al., 2013; David, Poissant, \& Rochette, 2012). Time is seen as essential to participate in a community and time availability is an important element to consider in the early stages of community development. However, as Walsh (2014) pointed out, face-to-face participation in a community would consume far more time than required to participate in a VCoP. 
Methods to overcome some of the issues of poor participation in VCoPs outlined in the papers included the need to increase levels of trust between members. It was also reported that more homogenous or 'focused' VCoPs the more interested and involved members were likely to be (Mairs et al., 2013). In addition, it was pointed out that successful VCoPs need knowledge discussed and shared by members needed to be applied to clinical practice (e.g. Mairs et al., 2013). Moreover, it was reported that professionals are more likely to be engaged if the $\mathrm{VCoP}$ is patient centered, and if guidelines and resources for translating research into practice were available in an easy-to-use formats and accessed at little or no cost (e.g. Vinson, 2014).

Leaders or facilitators can play an important role in encouraging active participation in a VCoP. Leaders have been identified as an import element in establishing and maintaining successful communities. They have been shown to contribute to improved collaboration within a VCoP through ensuing that rules of engagement are clear, keeping discussions focused while promoting engagement, shared respect and openness (e.g. Barnett et al., 2012).

Trust and Privacy. A number of the included papers noted issues with trust and privacy. Trust was reported as necessary to promote active participation and the generation of meaningful communication within the virtual communities. Trust between members was more likely to occur when members shared a common purpose and when they were provided with the opportunity to get to know one another (Mairs et al., 2013). It was also reported that a sense of equality and collective ownership can lead to the breaking down of professional silos and isolation (Swift, 2014). 
In CoPs, trust traditionally was established through face-to-face meetings and discussion. Developing trust can however be a challenge in VCoPs due to limited or no real-time interaction (Vinson, 2014). Offering asynchronous communication methods such as email or discussion forums, in addition to synchronous communication via social media networks can help overcome this situation (Barnett et al., 2012).

Issues with trust in virtual communities can have a significant impact on participation and the development of productive professional and interprofessional relationships. Lofters et al. (2016) for example found that participants in a VCoP were suspicious of the social media platform Facebook, even with privacy settings in place. As a result, the authors of this study reported poor participation by participants and note that reducing such fears and suspicions can be key to encouraging more active participation.

Technical ability. Many of the included papers reported issues with technical ability. Ease of use of the communication method was reported as an essential factor for VCoPs. In order for a virtual community to be successful, participants need to have a minimum level of technical competence regarding the use of ICTs (e.g. Maisonneuve et al., 2015). However, the learning curve needed for e-communication tools can be steep and obtaining a set of new technical skills requires time commitment from already busy health and social professionals (Lygidakis et al., 2016). In addition, it was evident from some of the papers that there was low competency of health professionals in using technology needed to engage in a successful VCoP (e.g. David et al., 2012). For example, in one of the studies that examined an online platform to support professional development found that nurses and other health professionals, even those who considered themselves as 'computer literate', required significant mentoring and support in the virtual environment (Frisch et al., 2014). 
It was noted that the development of these skills should commence during pre-qualifying education so graduates enter clinical practice with a solid foundation for collaborating in virtual environments (King et al., 2009; Lygidakis et al., 2016). Indeed, it was argued that to ensure interprofessional teams can collaborate effectively requires that students and practicing professionals learn how to communicate in both face-to-face and virtual environments (King et al., 2009).

\section{Discussion}

As presented above, this review found that the use of VCoPs were influenced by a number of issues such as technological infrastructure, participation, trust and privacy and technical ability. The review also reported a number of distinctive benefits to using VCoPs to help promote interprofessional learning and collaboration. VCoPs therefore appear to have a key role in the future of IPE and IPC as they provide an opportunity to overcome challenges linked to traditional forms of communication and interaction.

By the use of VCoPs, these challenges can be addressed in the following ways. Firstly, there are a large variety of web/internet tools available to use for VCoPs from wikis and blogs to social networks and discussion forums. These tools can be accessed anywhere, at any time by almost anyone. Furthermore, they allow for two-way communication, promoting active participation and collaboration. Secondly, VCoPs provide a safe environment where professional and interprofessional development can take place. Additionally, this low risk environment reduces professional barriers, not only within and between professions, encouraging effective communication and coordination. Thirdly, VCoPs afford the opportunity for professionals to engage in IPE and IPC activities - on a virtual basis - 
allowing individuals to engage with interprofessional interactions which many could not do so due to geographic barriers and/or time limitations. At the same time, VCoPs can offer a support network to health care professionals working in isolation.

Despite this potential, it must be recognized that recruiting and engaging members in virtual communities as well as ensuring their sustainability can be problematic. It has be suggested that for VCoPs to be successful a number of factors are required: members should be selfregulated and stimulated; have external support, supportive leadership, active facilitation and access to local champions (Ford et al., 2015). However, fostering active participation can be considered as the most important element to the success of a VCoP - as it is the members who generate the community's content. While participation can often be poor within VCoPs, it can be increased by addressing issues of privacy and trust through the creation of an encouraging and open environment - using appropriate technologies and allowing for synchronous communication. Utilizing a tool that students and professionals already use in their personal or professional life, such as social networks (e.g. Facebook, LinkedIn) can result in comfort and confidence in use, greater participation in the community and greater learning.

More research needs to be conducted into the effectiveness of VCoPs for interprofessional learning and collaboration. For example, studies should focus on addressing the following question: what are the best practices for using virtual communities and what areas should be improved to enhance their effectiveness for supporting IPE and IPC? Further research and evaluation work should aim to examine interaction processes as well as longer term outcomes on professional/interprofessional performance, collaborative behaviors and patient care. 
There are three key limitations to this review. First, only English-language articles were considered for inclusion in the study. As such, this review did not include potentially relevant materials published in other languages. Secondly, the review searched for materials published from 2000, which means any materials published before this date will not have been included. Third, only a partial range of grey literature was searched via Google Scholar. As a result, the review did not search, for example, primary care conferences for possible materials.

In summary, the use of VCoPs can be an effective method for supporting and enhancing IPE and IPC for time pressured health and social care professionals, as well as helping overcome geographical barriers to interprofessional interactions (Reeves, Fletcher, McLoughlin, Yim \& Patel, 2017). While VCoPs offer an informal method of professional/interprofessional development and collaboration for health and social care professionals. They can also decrease the social and professional isolation for professionals, especially working those in rural areas, improving knowledge sharing opportunities (Barnett et al., 2012). However for VCoPs to be successful, issues of privacy, trust, encouragement and technology must be addressed. VCoPs should continue to be monitored to assess suitability for IPE and IPC, sustainability, effects on quality of care, and lessons learned which can be applied to future communities.

\section{Notes}

1. For Facebook see: https://www.facebook.com/; For Twitter see: https://twitter.com/; For LinkedIn see: https://www.linkedin.com/

2. See: https://www.doximity.com/

\section{Declaration of Interest:}


The authors report no conflicts of interest. The authors alone are responsible for the content and writing of the article.

\section{References}

Abos Mendizabal, G., Nuño Solinís, R., \& Zaballa González, I. (2013). HOBE+, a case study: a virtual community of practice to support innovation in primary care in Basque Public Health Service. BMC Family Practice, 14, 168. http://doi.org/10.1186/14712296-14-168

Barnett, S., Jones, S. C., Bennett, S., Iverson, D., \& Bonney, A. (2012). General practice training and virtual communities of practice - a review of the literature. BMC Family Practice, 13, 87. http://doi.org/10.1186/1471-2296-13-87

Barnett, S., Jones, S. C., Bennett, S., Iverson, D., \& Bonney, A. (2013). Perceptions of family physician trainees and trainers regarding the usefulness of a virtual community of practice. Journal of Medical Internet Research, 15(5), e92. http://doi.org/10.2196/jmir.2555

Barnett, S., Jones, S. C., Bennett, S., Iverson, D., \& Robinson, L. (2016). A Virtual Community of Practice for General Practice Training: A Preimplementation Survey. JMIR Medical Education, 2(2), e13. http://doi.org/10.2196/mededu.5318

Barnett, S., Jones, S. C., Caton, T., Iverson, D., Bennett, S., \& Robinson, L. (2014). Implementing a virtual community of practice for family physician training: a mixedmethods case study. Journal of Medical Internet Research, 16(3), e83. http://doi.org/10.2196/jmir.3083

Barwick, M. (2008). Developing a Community of Practice Model for Cancer and Chronic Disease Prevention. Toronto, Canada. Retrieved from www.cdpac.ca

Cassidy, L. (2011). Online communities of practice to support collaborative mental health practice in rural areas. Issues in Mental Health Nursing, 32(2), 98-107. http://doi.org/10.3109/01612840.2010.535648

Curran, J. A., Murphy, A. L., Abidi, S. S. R., Sinclair, D., \& McGrath, P. J. (2009). Bridging the gap: knowledge seeking and sharing in a virtual community of emergency practice. Evaluation \& the Health Professions, 32(3), 312-25. http://doi.org/10.1177/0163278709338570

David, I., Poissant, L., \& Rochette, A. (2012). Clinicians' expectations of Web 2.0 as a mechanism for knowledge transfer of stroke best practices. Journal of Medical Internet Research, 14(5), e121. http://doi.org/10.2196/jmir.2016

Dong, C., Cheema, M., Samarasekera, D., \& Rajaratnam, V. (2015). Using LinkedIn for Continuing Community of Practice Among Hand Surgeons Worldwide. The Journal of Continuing Education in the Health Professions, 35(3), 185-91. http://doi.org/10.1002/chp.21300 
Evans, C., Yeung, E., Markoulakis, R., \& Guilcher, S. (2014). An online community of practice to support evidence-based physiotherapy practice in manual therapy. The Journal of Continuing Education in the Health Professions, 34(4), 215-23. http://doi.org/10.1002/chp.21253

Ford, J., Korjonen, H., Keswani, A., \& Hughes, E. (2015). Virtual communities of practice: can they support the prevention agenda in public health? Online Journal of Public Health Informatics, 7(2), e222. http://doi.org/10.5210/ojphi.v7i2.6031

Frenk, J., Chen, L., Bhutta, Z. A., Cohen, J., Crisp, N., Evans, T., ... Zurayk, H. (2010). Health professionals for a new century: Ttransforming education to strengthen health systems in an interdependent world. The Lancet, 376(9756), 1923-1958. http://doi.org/10.1016/S0140-6736(10)61854-5

Frisch, N., Atherton, P., Borycki, E., Mickelson, G., Cordeiro, J., Novak Lauscher, H., \& Black, A. (2014). Growing a professional network to over 3000 members in less than 4 years: evaluation of InspireNet, British Columbia's virtual nursing health services research network. Journal of Medical Internet Research, 16(2), e49. http://doi.org/10.2196/jmir.3018

Honeycutt, C., \& Herring, S. C. (2009). Beyond Microblogging: Conversation and Collaboration via Twitter. HICSS, 1-10. http://doi.org/10.1109/HICSS.2009.602

Ikioda, F., Kendall, S., Brooks, F., \& Reidy, C. (2014). Developing an online community of practice to empower health visitors: Findings from a pilot study. Journal of Health Visiting, 2(8), 436-440. http://doi.org/10.12968/johv.2014.2.8.436

King, S., Greidanus, E., Carbonaro, M., Drummond, J., \& Patterson, S. (2009). Merging social networking environments and formal learning environments to support and facilitate interprofessional instruction. Medical Education Online, 14, 5. http://doi.org/10.3885/meo.2009.T0000132

Wenger, E. (1998). Communities of practice: Learning, meaning, and identity. Cambridge University Press, Cambridge.

Lofters, A. K., Slater, M. B., Nicholas Angl, E., \& Leung, F.-H. (2016). Facebook as a tool for communication, collaboration, and informal knowledge exchange among members of a multisite family health team. Journal of Multidisciplinary Healthcare, 9, 29-34. http://doi.org/10.2147/JMDH.S94676

Lygidakis, H., McLoughlin, C., \& Patel, K. D. (2016). Achieving Universal Health Coverage: Technology for innovative primary health care education. Dublin.

Mairs, K., McNeil, H., McLeod, J., Prorok, J. C., \& Stolee, P. (2013). Online strategies to facilitate health-related knowledge transfer: a systematic search and review. Health Information and Libraries Journal, 30(4), 261-77. http://doi.org/10.1111/hir.12048

Maisonneuve, H., Chambe, J., Lorenzo, M., \& Pelaccia, T. (2015). How do general practice residents use social networking sites in asynchronous distance learning? BMC Medical Education, 15, 154. http://doi.org/10.1186/s12909-015-0435-x

Pullon, S. S., Wilson, C., Gallagher, P., Skinner, M., McKinlay, E., Gray, L., \& McHugh, P. 
(2016). Transition to practice: can rural interprofessional education make a difference? A cohort study. BMC Medical Education, 16(1), 154. http://doi.org/10.1186/s12909016-0674-5

Reeves S, Fletcher S, Barr H, Birch I, Boet S, Davies N, McFadyen A, Rivera J, Kitto S (2016) A BEME systematic review of the effects of interprofessional education: BEME Guide No. 39. Medical Teacher 38(7):656-68

Reeves S, Fletcher S, McLoughlin C, Yim A \& Patel KD (2017) Interprofessional online learning for primary healthcare: findings from a scoping review. BMJ Open; 0:e016872. doi:10.1136/bmjopen-2017-016872 .

Reeves S, Pelone F, Harrison R, Goldman J, Zwarenstein M. (2017) Interprofessional collaboration: effects of practice-based interventions on professional practice and healthcare outcomes (Update). Cochrane Database of Systematic Reviews. doi: 10.1002/14651858.CD000072.pub3.

Reeves S, Perrier L, Goldman J, Freeth D, Zwarenstein M (2013). Interprofessional education: effects on professional practice and healthcare outcomes (update). Cochrane Database of Systematic Reviews 2013, Issue 3. Art. No.: CD002213. DOI: 10.1002/14651858.CD002213.pub3

Spallek, H., Butler, B. S., Schleyer, T. K., Weiss, P. M., Wang, X., Thyvalikakath, T. P., ... Naderi, R. A. (2008). Supporting emerging disciplines with e-communities: needs and benefits. Journal of Medical Internet Research, 10(2), e19. http://doi.org/10.2196/jmir.971

Stewart, S. A., \& Abidi, S. S. R. (2012). Applying social network analysis to understand the knowledge sharing behaviour of practitioners in a clinical online discussion forum. Journal of Medical Internet Research, 14(6), e170. http://doi.org/10.2196/jmir.1982

Swift, L. (2014). Online communities of practice and their role in educational development: a systematic appraisal. Community Practitioner : The Journal of the Community Practitioners' \& Health Visitors' Association, 87(4), 28-31.

Thistlethwaite, J. (2012). Interprofessional education: a review of context, learning and the research agenda: Interprofessional education: a review. Medical Education, 46(1), 5870. http://doi.org/10.1111/j.1365-2923.2011.04143.x

Valaitis, R. K., Akhtar-Danesh, N., Brooks, F., Binks, S., \& Semogas, D. (2011). Online communities of practice as a communication resource for community health nurses working with homeless persons. Journal of Advanced Nursing, 67(6), 1273-84. http://doi.org/10.1111/j.1365-2648.2010.05582.x

Vinson, C. A. (2014). Using concept mapping to develop a conceptual framework for creating virtual communities of practice to translate cancer research into practice. Preventing Chronic Disease, 11, E68. http://doi.org/10.5888/pcd11.130280

Walsh, K. (2014). Virtual communities of practice: overcoming barriers of time and technology. Journal of Medical Internet Research, 16(7), e185.

http://doi.org/10.2196/jmir.3400 
Whittemore, R., \& Knafl, K. (2005). The integrative review: updated methodology. Journal of Advanced Nursing, 52(5), 546-553. http://doi.org/10.1111/j.1365-2648.2005.03621.x

World Health Organization. (2013). Transforming and scaling up health professionals' education and training: World Health Organization guidelines 2013. Retrieved from http://apps.who.int/iris/handle/10665/93635 
Table 1. Benefits of CoPs (Barwick, 2008; Ford et al., 2015)

\begin{tabular}{|l|l|}
\hline Short Term & Long Term \\
\hline $\begin{array}{l}\text { Rapid identification of skills set within the } \\
\text { workforce }\end{array}$ & $\begin{array}{l}\text { Providing a forum for expanding skills and } \\
\text { expertise }\end{array}$ \\
\hline Knowledge sharing & Provide a network for current awareness \\
\hline Providing safe environments & Help foster a sense of professional identity \\
\hline Capture and reuse of existing knowledge & \\
\hline Improvements in topical knowledge & \\
\hline $\begin{array}{l}\text { Improvements in the rate of implementation } \\
\text { of evidence-based practice }\end{array}$ & \\
\hline
\end{tabular}

Table 2: Overview of included papers

\begin{tabular}{|l|l|l|l|l|l|}
\hline Citation & Title & Setting & Study Design & $\begin{array}{l}\text { Data } \\
\text { collection } \\
\text { method }\end{array}$ & $\begin{array}{l}\text { Sample } \\
\text { size }\end{array}$ \\
\hline $\begin{array}{l}\text { Abos } \\
\text { Mendizabal, } \\
\text { Nuño Solinís } \\
\text { \& Zaballa } \\
\text { González } \\
(2013)\end{array}$ & $\begin{array}{l}\text { HOBE+, a case study: a } \\
\text { virtual community of } \\
\text { practice to support } \\
\text { innovation in primary } \\
\text { care in Basque Public } \\
\text { Health Service }\end{array}$ & $\begin{array}{l}\text { Primary } \\
\text { Care }\end{array}$ & Case Study & Survey & $\mathrm{n}=233$ \\
\hline $\begin{array}{l}\text { Barnett et al. } \\
(2012)\end{array}$ & $\begin{array}{l}\text { General practice training } \\
\text { and virtual communities } \\
\text { of practice - a review of } \\
\text { the literature }\end{array}$ & $\begin{array}{l}\text { Primary } \\
\text { Care }\end{array}$ & $\begin{array}{l}\text { Literature } \\
\text { Review }\end{array}$ & $\begin{array}{l}\text { Literature } \\
\text { search }\end{array}$ & NA \\
\hline $\begin{array}{l}\text { Barnett et al. } \\
(2013)\end{array}$ & $\begin{array}{l}\text { Perceptions of family } \\
\text { physician trainees and } \\
\text { trainers regarding the } \\
\text { usefulness of a virtual } \\
\text { community of practice. }\end{array}$ & $\begin{array}{l}\text { Primary } \\
\text { Care }\end{array}$ & Case Study & Survey & $\mathrm{n}=131$ \\
\hline $\begin{array}{l}\text { Barnett et al. } \\
(2014)\end{array}$ & $\begin{array}{l}\text { Implementing a Virtual } \\
\text { Community of Practice } \\
\text { for Family Physician } \\
\text { Training: A Mixed- } \\
\text { Methods Case Study }\end{array}$ & $\begin{array}{l}\text { Primary } \\
\text { Care }\end{array}$ & Case Study & $\begin{array}{l}\text { Survey and } \\
\text { interviews }\end{array}$ & $\mathrm{n}=55$ \\
\hline Barnett et al. & A Virtual Community & Primary & Mixed & Survey & $\mathrm{n}=133$ \\
\hline
\end{tabular}




\begin{tabular}{|c|c|c|c|c|c|}
\hline (2016) & $\begin{array}{l}\text { of Practice for General } \\
\text { Practice Training: A } \\
\text { Pre-implementation } \\
\text { Survey }\end{array}$ & Care & methods & & \\
\hline $\begin{array}{l}\text { David, } \\
\text { Poissant \& } \\
\text { Rochette } \\
(2012)\end{array}$ & $\begin{array}{l}\text { Clinicians' expectations } \\
\text { of Web } 2.0 \text { as a } \\
\text { mechanism for } \\
\text { knowledge transfer of } \\
\text { stroke best practices. }\end{array}$ & $\begin{array}{l}\text { Stroke } \\
\text { Network }\end{array}$ & Case study & $\begin{array}{l}\text { Individual } \\
\text { semi- } \\
\text { structured } \\
\text { interviews }\end{array}$ & $\mathrm{n}=20$ \\
\hline $\begin{array}{l}\text { Dong et al. } \\
\text { (2015) }\end{array}$ & $\begin{array}{l}\text { Using LinkedIn for } \\
\text { Continuing Community } \\
\text { of Practice Among Hand } \\
\text { Surgeons Worldwide }\end{array}$ & $\begin{array}{l}\text { Secondary } \\
\text { Care }\end{array}$ & $\begin{array}{l}\text { Observational } \\
\text { Study }\end{array}$ & $\begin{array}{l}\text { Web analysis } \\
\text { and surveys }\end{array}$ & $\mathrm{N}=500$ \\
\hline $\begin{array}{l}\text { Evans et al. } \\
\text { (2014) }\end{array}$ & $\begin{array}{l}\text { An online community of } \\
\text { practice to support } \\
\text { evidence-based } \\
\text { physiotherapy practice } \\
\text { in manual therapy }\end{array}$ & $\begin{array}{l}\text { Primary } \\
\text { Care }\end{array}$ & $\begin{array}{l}\text { Observational } \\
\text { Study }\end{array}$ & $\begin{array}{l}\text { Qualitative } \\
\text { analysis of } \\
\text { discussion } \\
\text { board } \\
\text { contributions }\end{array}$ & $\mathrm{n}=19$ \\
\hline $\begin{array}{l}\text { Ford et al. } \\
\text { (2015) }\end{array}$ & $\begin{array}{l}\text { Virtual communities of } \\
\text { practice: can they } \\
\text { support the prevention } \\
\text { agenda in public health? }\end{array}$ & $\begin{array}{l}\text { Public } \\
\text { Health }\end{array}$ & Case study & $\begin{array}{l}\text { Survey, web } \\
\text { analysis }\end{array}$ & $\mathrm{N}=145$ \\
\hline $\begin{array}{l}\text { Frisch et al. } \\
\text { (2014) }\end{array}$ & $\begin{array}{l}\text { Growing a professional } \\
\text { network to over } 3000 \\
\text { members in less than } 4 \\
\text { years: evaluation of } \\
\text { InspireNet, British } \\
\text { Columbia's virtual } \\
\text { nursing health services } \\
\text { research network. }\end{array}$ & $\begin{array}{l}\text { Primary } \\
\text { and } \\
\text { Secondary } \\
\text { Care }\end{array}$ & Case study & $\begin{array}{l}\text { Web analysis, } \\
\text { survey, } \\
\text { interviews, } \\
\text { focus group }\end{array}$ & $\mathrm{n}=44$ \\
\hline $\begin{array}{l}\text { Ikioda, } \\
\text { Kendall, } \\
\text { Brooks \& } \\
\text { Reidy (2014) }\end{array}$ & $\begin{array}{l}\text { Developing an online } \\
\text { community of practice } \\
\text { to empower health } \\
\text { visitors: Findings from a } \\
\text { pilot study }\end{array}$ & $\begin{array}{l}\text { Primary } \\
\text { care }\end{array}$ & Case study & & \\
\hline $\begin{array}{l}\text { King et al. } \\
(2009)\end{array}$ & $\begin{array}{l}\text { Merging social } \\
\text { networking } \\
\text { environments and } \\
\text { formal learning } \\
\text { environments to support } \\
\text { and facilitate } \\
\text { interprofessional } \\
\text { instruction. }\end{array}$ & $\begin{array}{l}\text { Educational } \\
\text { setting }\end{array}$ & Case study & Web analysis & $\mathrm{n}=620$ \\
\hline $\begin{array}{l}\text { Lofters, } \\
\text { Slater } \\
\text { Nicholas, }\end{array}$ & $\begin{array}{l}\text { Facebook as a tool for } \\
\text { communication, } \\
\text { collaboration, and }\end{array}$ & $\begin{array}{l}\text { Primary } \\
\text { Care }\end{array}$ & Case Study & $\begin{array}{l}\text { Web analysis, } \\
\text { Survey }\end{array}$ & $\mathrm{N}=115$ \\
\hline
\end{tabular}




\begin{tabular}{|c|c|c|c|c|c|}
\hline $\begin{array}{l}\text { Angel \& } \\
\text { Leung } \\
(2016)\end{array}$ & $\begin{array}{l}\text { informal knowledge } \\
\text { exchange among } \\
\text { members of a multisite } \\
\text { family health team. }\end{array}$ & & & & \\
\hline $\begin{array}{l}\text { Mairs et al } \\
\text { (2013) }\end{array}$ & $\begin{array}{l}\text { Online strategies to } \\
\text { facilitate health-related } \\
\text { knowledge transfer: a } \\
\text { systematic search and } \\
\text { review }\end{array}$ & $\begin{array}{l}\text { Primary } \\
\text { Care, } \\
\text { Secondary } \\
\text { Care }\end{array}$ & $\begin{array}{l}\text { Systematic } \\
\text { review }\end{array}$ & $\begin{array}{l}\text { Literature } \\
\text { search }\end{array}$ & $\mathrm{NA}$ \\
\hline $\begin{array}{l}\text { Maisonneuve } \\
\text { et al (2015) }\end{array}$ & $\begin{array}{l}\text { How do general practice } \\
\text { residents use social } \\
\text { networking sites in } \\
\text { asynchronous distance } \\
\text { learning? }\end{array}$ & $\begin{array}{l}\text { Primary } \\
\text { Care, } \\
\text { Educational } \\
\text { Setting }\end{array}$ & Case study & $\begin{array}{l}\text { Semi- } \\
\text { structured } \\
\text { interviews }\end{array}$ & $\mathrm{n}=40$ \\
\hline $\begin{array}{l}\text { Pullon et al } \\
\text { (2016) }\end{array}$ & $\begin{array}{l}\text { Transition to practice: } \\
\text { can rural } \\
\text { interprofessional } \\
\text { education make a } \\
\text { difference? A cohort } \\
\text { study }\end{array}$ & $\begin{array}{l}\text { Primary } \\
\text { Care, } \\
\text { Secondary } \\
\text { Care, } \\
\text { Educational } \\
\text { Setting }\end{array}$ & $\begin{array}{l}\text { Quasi- } \\
\text { experimental } \\
\text { cohort study }\end{array}$ & Survey & $\mathrm{n}=131$ \\
\hline $\begin{array}{l}\text { Stewart \& } \\
\text { Abidi, } \\
\text { (2012) }\end{array}$ & $\begin{array}{l}\text { Applying social network } \\
\text { analysis to understand } \\
\text { the knowledge sharing } \\
\text { behaviour of } \\
\text { practitioners in a clinical } \\
\text { online discussion forum. }\end{array}$ & $\begin{array}{l}\text { Secondary } \\
\text { Care }\end{array}$ & Case study & Web analysis & NA \\
\hline Swift (2014) & $\begin{array}{l}\text { Online communities of } \\
\text { practice and their role in } \\
\text { educational } \\
\text { development: a } \\
\text { systematic appraisal. }\end{array}$ & $\begin{array}{l}\text { Educational } \\
\text { Setting }\end{array}$ & $\begin{array}{l}\text { Systematic } \\
\text { review }\end{array}$ & $\begin{array}{l}\text { Literature } \\
\text { search }\end{array}$ & NA \\
\hline $\begin{array}{l}\text { Vinson } \\
\text { (2014) }\end{array}$ & $\begin{array}{l}\text { Online communities of } \\
\text { practice as a } \\
\text { communication resource } \\
\text { for community health } \\
\text { nurses working with } \\
\text { homeless persons. }\end{array}$ & $\begin{array}{l}\text { Primary } \\
\text { Care }\end{array}$ & $\begin{array}{l}\text { Q- } \\
\text { methodology }\end{array}$ & $\begin{array}{l}\text { Surveys, } \\
\text { focus group }\end{array}$ & $\mathrm{n}=16$ \\
\hline
\end{tabular}


